201 JØRN BOISEN

Lektor

Fransk, Københavns Universitet

\title{
GLOBALE STREJFTOG I NY FRANSK LITTERATUR
}

Mads Anders Baggesgaard

NYE FRANSKE VERDENER

292 sider. Aarhus Universitetsforlag, Aarhus, 2016

Det vil nok være på sin plads at komme med en såkaldt disclaimer i stil med de advarsler, som man placerer på cigaretpakker eller sange med bandeord, inden jeg giver mig i kast med selve anmeldelsen af Mads Anders Baggesgaards bog om fransk litteratur i globaliseringens tid.

Jeg har baggrund i en lidt anden faglighed end forfatteren til denne bog. Jeg er uddannet i den klassiske sprogfagstradition, hvor det er afgørende, at litteratur, hi- storie og kultur opleves og erkendes gennem sproget. Det gælder ideelt om at opleve kulturen indefra. Baggesgaard har, så vidt jeg kan vurdere, et lidt andet paradigme, der ikke er afgørende forskelligt, men som alligevel rummer et par interessante forskydninger. Det gælder stadig om at forstå en kultur i dens komplekse fremtrædelsesformer og analysere den sociale og politiske kontekst, i hvilken den manifesterer sig, men perspektivet er anderledes. Blikket kommer udefra, teorien fylder mere, sprog og kendskab til lokale forhold fylder mindre; det er mere orienteret mod nutiden, og i baggrunden lurer en trang til at moralisere. Hvor 
202 KULTUR \& KLASSE * $127 * 2019$ ANMELDELSER
203 JØRN BOISEN

GLOBALE STREJFTOG I NY FRANSK LITTERATUR faren ved den første tilgang er, at forskeren går native, er faren ved den anden, at hele verden opfattes som en petting zoo, og de andre er gederne.

Jeg beklager dette præambel, men det er kun fair, at jeg definerer mit eget ståsted, og at jeg definerer det i forhold til en spænding, som jeg kan konstatere i Mads Anders Baggesgaards bog Nye Franske Verdner, for han står med et ben plantet i hver lejr. Baggesgaard formulerer selv en eksplicit spænding mellem det abstrakt geopolitiske (globaliseringen) og det konkret tids- og stedsspecifikke (ny fransk litteratur). Der er imidlertid også en implicit spænding i selve bogens læsninger, for hvor går læsningerne hen? Hvad vil de gerne gøre os klogere på? Hvor placerer de sig mellem det ældre filologiske paradigme og det mere moderne cultural studies-paradigme?

Denne spænding er ikke i sig selv et problem. Bogen er et eksempel på, at et dobbelt ståsted godt kan være udgangspunkt for en række interessante læsninger. Men skal man vurdere, om bogen som samlet værk lykkes med sit forehavende, er det straks mere problematisk, for hvad er det egentlig den vil? Er teksterne en illustration af en bre- dere globaliseringsteori anvendt på Frankrig? Eller bliver globaliseringsoptikken brugt som et middel til at forstå og udfolde de enkelte tekster?

Det oplagte svar er, at de to perspektiver skal belyse og berige hinanden.

Det lykkes efter min mening ikke helt.

\section{DET GODE FØRST.}

Det er et knaldgodt emne. Der er ingen, der tænker så meget over krise, globalisering og litteratur som de franske, i særdeleshed de franske litterater, og der er virkelig mange spændende perspektiver på sagen i Baggesgaards bog. Bogen er derudover sprogligt veloplagt, velformuleret og lærd uden at være uforståelig. Og så laver Aarhus Universitetsforlag altså virkelig flotte bøger; det er en smuk og gennemarbejdet udgivelse i en i øvrigt spændende udgivelsesrække.

Det er også tydeligt, at Baggesgaard har et solidt og præcist kendskab inden for feltet. De diskussioner, som han tager op, er relevante, og han går ind i dem med den nødvendige indsigt.

Det er lidt sværere at spidsformulere mine forbehold, men vi kan jo starte med bogens gennemgående og grundlæggende tema, globaliseringen. Forfatteren har en lang indledende diskussion af begrebet globalisering, hvad det er, hvad det betyder for litteraturen for historien, for litteraturhistorien og for Frankrig. Det er en glimrende forskningsoversigt, der præsenterer de nyeste litterære, idéhistoriske og filosofiske perspektiver på globaliseringens tidsalder.

Problemet - i mine øjne er, at fænomenet "globalisering" ikke tilhører samme kategori som fænomenet "postmoderne" eller "postmodernisme". Globalisering er noget andet og meget mere end en genre- eller periodebetegnelse, som litterater kan tage ejerskab og spinde skarpe pointer over. Et næsten tilfældigt eksempel: "White diskvalificerer med udgangspunkt i de forskellige bidrag selve forestillingen om en historie, fordi globaliseringen umuliggør selve ideen om et historisk objekt endsige subjekt. I globaliseringen er der ingen forgrund og baggrund og derfor heller ingen distance mellem begivenheder, institutioner og tekster [...]" (53).

Det er nok rigtigt. Alligeve virker det for mig urimeligt akademisk navlebeskuende at tage et begreb, der beskriver livsvilkårene for samtlige klodens beboere, og se det som et litteraturhistorisk problem. Naturligvis er det også et litteraturhistorisk problem, men "globalisering" er ikke en æstetisk kategori. Globalisering er afpolitisering af økonomi, afdemokratisering af politik, konkurrenceudsættelse af alle funktioner, outsourcing, digitalisering, sociale medier, fake news, migration og klimakrise. Globalisering er grunden til, at amerikanerne stemmer på Trump, at briterne stemmer sig ud af EU, og at franskmændene tager gule veste på og prøver at smadre Paris. De er grunden til, at middelklassen i Vesten frygter for deres job, for deres pensioner og for deres børns fremtid.

Det polycentriske, som Hayden White med stor veltalenhed er inde på, er ganske rigtigt et særtræk ved globaliseringen, men det er dybest set irrelevant, for når den franske litteratur og den franske debat forholder sig til globaliseringen, er det altså ikke til globaliseringen som koncept. Den forholder sig til globaliseringen som realitet.

Det bliver tydeligt, så snart Baggesgaard konkretiserer diskussionen. Den indledes (veloplagt!) med et nedslag i Frédéric Beigbe- 
204 KULTUR \& KLASSE $* 127 * 2019$ ANMELDELSER
205 JØRN BOISEN

GLOBALE STREJFTOG I NY FRANSK LITTERATUR ders roman Un roman français (en fransk roman) fra 2009, der uden videre omsvøb og helt konkret formulerer de franskes oplevelse af globaliseringen. Franskmændene er præget af en dyb kulturpessimisme og en form for selvhad, der konstant italesættes i litteraturen (selvom Beigbeder gør det med en god portion humor). Der er en ekstrem skepsis over for globaliseringen i alle dens økonomiske og politiske aspekter. Der er imidlertid et aspekt, der bliver lidt underbelyst i Baggesgaards fremstilling: Kulturelt er Frankrig en totalt xenofil nation. De elsker og hylder fremmede og nye stemmer inden for musik film og litteratur. Det er ikke et tilfælde, at den danske Dogme-bevægelse gik sin sejrsgang verden over med Frankrig som udgangspunkt. Der er en ægte interesse for, hvad der kommer udefra. Der er en stolthed over denne interesse. Der er en glæde over, at Paris stadig udfylder en rolle, som ingen andre tager på sig. Den franske kulturscene er entusiastisk global. Dette forhold - økonomisk protektionisme og maksimal kulturel åbenhed - bliver blandet sammen i bogen til en almen skepsis mod omverdenen stedet for at blive foldet ud, som det paradoks det egentlig er.
Det er imidlertid mindre indvendinger. Det, som jeg til syvende og sidst savner i diskussionen af "globaliseringen", er, at Baggesgaard definerer, hvad begrebet er for ham. Hvad er det, som han har tænkt sig at operationalisere og anvende i sin læsning? Efter den sprænglærde diskussion er læseren behørigt oplyst, men ikke ret meget klogere på, hvad han eller hun forventes at stille op med begrebet, for det er så monumentalt, at det mister forklaringskraft: Alt er i spil hele tiden og på alle planer. Jeg synes, at det i et værk som dette er forfatterens opgave at brede kortet ud og anvise et mål og en retning. Kortet bliver bredt ud med en vis kompetence, men når der ikke samtidig bliver defineret et fokus, bliver "globalisering" en tilstand og et vilkår på linje med tyngdekraften i stedet for at blive operationaliseret som et analytisk begreb, der kan give mål og retning i de efterfølgende læsninger.

Man kan altid protestere mod udvalget af forfattere, og det vil jeg ikke holde mig for god til, for jeg fatter det simpelthen ikke. Baggesgaard skriver side 58, at det er de forskellige sammenspil mellem store og små historier, der er emnet for bogen og rammen for analysen. Fint nok, men alligevel ikke helt fint, når læseren ikke er i stand til at bestemme, hvilke kri terier og tanker der ligger til grund for udvælgelsen, især fordi flere af teksterne virker umiddelbart marginale i forhold til globaliseringsproblematikken. Her falder vi igen tilbage på mit første forbehold: Hvad taler vi om, når vi taler om globalisering? Er Jonathan Littell global, fordi han er en amerikaner, der skriver på fransk? Er Perec global, fordi han er inspireret af internationale strømninger? Er François Bon global, fordi han har navngivet en roman efter en kore ansk industrimastodont? Svaret blæser i de globale vinde.

Den første analyse handler om bogmarked, forlagspolitik og reception og genstanden er Jonathan Littells Les bienveillantes (De velvillige). Indgangsbønnen er økonomisk, udgivelsespolitisk og merkantil. Her er globalisering altså markedet. Det er en legitim vinkel. Der bliver ikke sagt ret meget kvalitativt om De Velvillige, og det, der siges, er mestendels andenhånds. Julia Kristeva citeres for sin (forkerte) antagelse, at Les bienveillantes er den første krigsroman, hvor synsvinklen er bødlens ( $L a$ mort est mon métier (døden er min metiér) af Robert Merle fra 1952 har samme vinkel). Senere refereres kritikker af romanen for at "foregive at præsentere en radikal og nyskabende refleksion [...], men gør det i en form, der er modelleret over Hollywoods skabelon for narrativ forståelighed" (p. 64). Det synes jeg også er helt ved siden af skiven, men hvor står Baggesgaard selv? Han er (vist) mest enig i kri tikken af Littell: mere spekulation end kunst. Begejstringen for bogen i Frankrig skyldes (vist) mest den provinsielle benovelse over, at en amerikaner har valgt at skrive en roman på fransk. Well.

Ellers er valget af Littell et af de valg, som jeg virkelig godt kan forstå. Jeg kan også godt forstå, at det er receptionen, der er fokus. Til gengæld synes jeg, at der er mere interessante pointer, der kunne fremføres, selv når man begrænser sig til det valgte fokus. Alle kender markedets vilkår og virkemidler. Det er der ikke noget spændende i. Det spændende er det, der sker, når den samme genstand sendes rundt i forskellige kulturelle systemer og får vidt forskellig respons. Her har Baggesgaard set rigtigt. Littells roman udgør et fantastisk undersøgelsesobjekt, fordi responsen er så determineret af bagvedliggende 
206 KULTUR \& KLASSE $* 127 * 2019$

ANMELDELSER
207 JØRN BOISEN

GLOBALE STREJFTOG I NY FRANSK LITTERATUR og uudtalte moralske strukturer og værdisystemer. Lige præcis De velvillige blotlægger en mangel ved den globaliserede kultur, nemlig at den eneste acceptable reaktion på moralsk tvetydige situationer er tabuisering. Den diskussion kommer desværre ikke rigtig til at løfte sig.

I stedet sætter Baggesgaard Littells succes i forbindelse med André Malraux' og Charles de Gaulles kulturpolitik fra 1960'erne. Forfatteren, kommunisten og eventyreren Malraux var efter krigen muteret til overbevist gaullist og en ret original kulturteoretiker og hans store præstation er det netværk af kulturhuse, maisons de la culture, som man stadig kan finde rester af rundt omkring i Frankrig. Baggesgaards præsentation af kulturhusene kan beskrives som spidsvinklet (og stikordet kommer ikke overraskende fra en amerikansk forsker): Deres hovedfunktion var åbenbart at fungere som kosteskab hvor man kunne opbevare koloniadministratorer, som der ikke længere var brug for. I det hele taget er vinklen, at kultur udelukkende er et instrument til magt. Tanken at Malraux og de Gaulle et sekund skulle mene, hvad de skrev i deres tykke bøger om kunst og kultur bliver ikke taget seriøst.
Bortset fra det er afsnittet om fransk kulturpolitik både oplysende og velinformeret. Det er dog ikke helt klart for mig, hvad globaliseringsprismen bringer af værdi til analysen. Det er et kapitel om markedsandele, kulturfremstød og soft power, om amerikansk hegemoni og franske undtagelser, og det kan man da godt kalde for globalisering, og man kan lige så godt lade være, og det burde man. I den verden, hvor de Gaulle og Malraux agerer, er nationalstaten den altafgørende horisont, inden for hvilken, den gør, hvad pokker den vil. Det er en verden, der intet har at gøre med nutidens globalisering. (Det interessante er i øvrigt ikke, at Frankrig tilsyneladende har en officiel holdning til syndfloden af middelmådige amerikanske produkter; det interessante er, at de tilsyneladende er de eneste, der har en holdning.) Under alle omstændigheder bliver Littells stakkels roman spændt for en vogn, som den umuligt kan trække.

Efter Littell springer vi til Yasmina Rezas bog om Sarkozy L'aube le soir ou la nuit (daggry, aften eller nat). Hvad er forbindelsen? spørger man. Ingen forbindelse, bortset fra, at begge bøger har en vis kvalitet og fik en del omtale. Hvad er relevansen? Det er uklart, men Rezas bog bruges som anledning til at fortsætte analysen af fransk kulturpolitik, denne gang med Sarkozy-tiden som omdrejningspunkt. Igen er afsnittet både spændende, velskrevet og velinformeret. Det har bare ikke ret meget med litteratur at gøre, og det har heller ikke ret meget med globalisering at gøre.

Man kan tilgive misforståelsen, for Sarkozy ligner på overfladen en fænomenal god case: søn af indvandrere med hård retorik mod indvandrere. Men skinnet bedrager. Sarkozy er pærefransk (franchouillard ville man sige på fransk), der er intet globaliseret over den måde, han tænker og agerer på heller ikke selv om hans navn er udenlandsk. Med hensyn til indvandring er han en faux dur - han har det hele i munden. Identitetsspørgsmålet blev brugt valgstrategisk, men reelt var det varm luft. Tematisk er der perfekt kontinuitet mellem Chirac, Sarkozy og Hollande, og temaerne er afmagt, bluff og tomhed.

For at fortsætte i samme spor. Det næste kapitel handler om George Perec. Det er virkelig godt, og det har intet med bogens tema at gøre. Perec døde i 1982, og hans død falder sammen med, at begrebet globalisering bruges første gang. Det ville svare til at give Leif Panduro en fremtrædende plads i en bog om dansk samtidslitteraturs forhold til globaliseringen. Afsnittet om François Bons Daewoo passer til gengæld perfekt. Det er et rig tig fint kapitel, der skriver sig ind bogens perspektiver, fransk litteraturhistorie, fransk samtidslitteratur og globaliseringens problemer.

Derved afslører kapitlet om Daewoo også Nye Franske Verdeners overordnede mangel på enhed og linje.

Min kritiske galde er konstant blevet holdt flydende, fordi jeg som læser føler, at jeg bliver manipuleret til at skulle se en sammenhæng, der ikke er der. Alle de ovenstående kritiske bemærkninger er affødt af dette. Efter flere gennemlæsninger er det omsider gået op for mig, at jeg ville have nydt bogen utrolig meget mere, hvis den havde taget sin episodiske natur på sig. Bogen burde have haft en langt mere nonchalant og gammeldags elastisk titel som f.eks. Strejftog i Nyere Fransk Litteratur. Der er jo før udgivet bøger, der samler tematisk forbundne, men dybest set selvstændige tekster. Man skal bare stå ved, at det er det, man gør. 
Vi har en række kapitler, der faktisk alle har noget at byde på. Jeg synes, at Baggesgaard kunne have fået noget mere spændende ud af Littell-kapitlet, men ellers er kapitlerne hver for sig både gode og interessante, også den indledende teoretiske diskussion. Frustrationen hos mig opstår, når bogen leveres med forkert varedeklaration, når der konstant hugges hæle og klippes tæer, så teksterne kan passes ind i et overordnet, men tiltagende amorft globaliseringsbegreb. Derfor er jeg kommet til at fokusere på netop det, der ikke er der (nemlig en stærk sammenhæng), og ikke så meget på det, der rent faktisk står i kapitlerne. Jeg vil kraftigt opfordre kommende læsere til at læse kapitlerne som selvstændige bidrag. Så kan man nyde, hvad de har at tilbyde, uden at blive frustreret over, at de ikke nødvendigvis hænger sammen med næste kapitel.

Således ender Nye Franske Verdener med at være en omvendt illustration af det gamle Clemenceau-citat: "La guerre est une série de catastrophes qui se terminent par une victoire." - krig er en række katastrofer, der ender med en sejr: Denne bog er en række sejre, der ender med et nederlag. Det er ikke en bog, som man skal læse på dens egne præmisser. Man skal læse den på kapitlernes præmisser. 